\title{
ADAMTS9 Gene
}

National Cancer Institute

\section{Source}

National Cancer Institute. ADAMTS9 Gene. NCI Thesaurus. Code C21278.

This gene plays a role in apoptosis and development. 